\title{
Influence of Personality and Self-Esteem on the Academic Procrastination among University Students
}

\author{
Vijay, M. $^{1 *}$, Kadhiravan, S. ${ }^{2}$
}

\section{ABSTRACT}

Personality refers to a dynamic and unique organization which determines the characteristic behavior of people. It predominantly influences the life in various domains. There are many factors which could influence people's behaviour in constantly changing environment. One such factor is self-esteem, which reflect overall emotional evaluation about their self-worthiness to get succeed in life. Academic procrastination indicates individuals' tendency to delay or put off academic activities. This is closely associated with the self-esteem. Also, the characteristic structure could have an influence on academic procrastination. An attempt was made in this study to study the influence of personality and self-esteem on the academic procrastination among university students. 150 university students were selected through simple random sampling for this purpose and the data was collected through a survey. Results revealed that the academic procrastination of university students have significant negative relationship with their self-esteem. Some of the personality factors have significant association with their academic procrastination. The findings and implications are presented in the article.

Keywords: Personality, Self-Esteem, Academic Procrastination

Personality refers to an individual's organized pattern of behavioural characteristics such as, physical, mental and social characteristics which directly or indirectly influences person's life in different domains (Funder, 1997). There are many factors relate to the development of personality. One such factor is self-esteem, which reflects a people's overall emotional evaluation about their self-worthiness to get succeed in life (Crocker \& Wolfe, 2001). In educational setting it plays a prudent role in students' academic performance. Arshad (2015) indicated that, "self-esteem is negatively correlated with neuroticism personality factor and positively associated with academic performance. Higher self-esteem reflects students' good academic performance and neuroticism reflects students' lack of academic performance, where as lower self-esteem may leads to increase students stress level”. Lack of academic performance

\footnotetext{
${ }^{1}$ Research Scholar, Department of Psychology, Periyar University, Salem, Tamil Nadu, India

${ }^{2}$ Professor \& Head, Department of Psychology, Periyar University, Salem, Tamil Nadu, India

*Responding Author

(C) 2016 Vijay M, Kadhiravan S; licensee IJIP. This is an Open Access Research distributed under the terms of the Creative Commons Attribution License (http://creativecommons.org/licenses/by/2.0), which permits unrestricted use, distribution, and reproduction in any Medium, provided the original work is properly cited.
} 
may lead to of procrastination. According to Lay (1986) "procrastination is the tendency to delay initiation or completion of important tasks”. Solomon and Rothblum (1984) defined procrastination as "to put off tasks to the point of discomfort and it is a complex phenomenon with cognitive, affective, and behavioral components". Hakan Karatas (2015) indicated that "procrastination can be viewed as a personality trait, which is based on decisional making and routine of daily living: as well as conditional procrastination, which includes academic procrastination”. In educational setting, academic procrastination is commonly known as delaying academic activities. Hussain and Sultan (2010) opined that, "lack of commitment, lack of guidance and encouragement, inappropriate time management skills, emotional stress, social problems, overconfidence and illness were commonly appeared in students’ educational life».

\section{NEED FOR THE STUDY}

People are committed with various activities in their life. Due to some additional responsibilities they tend to forget or fail to complete their tasks. In today's educational setting, students in universities are compelled to engage with various curricular and co-curricular activities in a short duration. For instance, writing assignment, preparation for seminar presentation, attending the internal as well external examination for different subjects and so on. In these circumstances, procrastination appears and students tend to postpone their academic work. At the same time, some students deliberately postpone their work due to their involvement in extracurricular activities, lack of interest and laziness. Generally, it is witnessed that academic procrastination affects students' learning outcomes in turn affect students' self-worthiness and confidence which could have serious repercussions in their career. Self-esteem helps people to make better evaluation of themselves and it lay a foundation for the development of personality. Personality factors determine characteristic/situational behaviour and procrastination is predominantly a situational behaviour. Hence, assessing the influence of personality and self-esteem on academic procrastination among university students would be useful to suggest suitable measures to students to overcome their procrastination and improve academic performance.

\section{Hypotheses}

1. Personality and self-esteem of university students have a significant influence on their academic procrastination.

2. Students differ significantly in their academic procrastination, on the basis of gender, stream of study, type of family and locality.

\section{RESEARCH METHOD}

The present study aimed at assessing the influence of personality factors and self-esteem on academic procrastination among university students. 150 students from Periyar University were selected through simple random sampling and the data was collected through survey. The procrastination scale (Lay, 1986), self-esteem scale (Rosenberg, 1987) and NEO-Big-Five factor 
Personality factors scale (McCrae \& Costa, 1992) were used to collect the data. Out of the 150 data collected only 137 were considered for analysis.

\section{RESULTS AND DISCUSSION}

Table: 1 Influence of Personality Factors and Self-Esteem on the Academic Procrastination of University Students: Regression Analysis

\begin{tabular}{|c|c|c|c|c|c|c|}
\hline \multirow{2}{*}{$\begin{array}{c}\text { Independent } \\
\text { variable }\end{array}$} & \multirow{2}{*}{$\begin{array}{c}\text { Dependent } \\
\text { variable }\end{array}$} & \multicolumn{2}{|c|}{$\begin{array}{l}\text { Un-standardized } \\
\text { Coefficients }\end{array}$} & \multirow[t]{2}{*}{ Beta } & \multirow[t]{2}{*}{ ' $t$ ' } & \multirow[t]{2}{*}{$\begin{array}{c}\text { Model } \\
\text { Summary }\end{array}$} \\
\hline & & B & S.E & & & \\
\hline Neuroticism & & 0.634 & 0.176 & 0.376 & 3.597* & \\
\hline Self-Esteem & $\begin{array}{c}\text { Academic } \\
\text { Procrastination }\end{array}$ & -0.540 & 0.175 & -0.370 & 3.095* & $\begin{array}{c}\mathrm{R}^{2}=0.21 \\
\mathrm{~F}=4.146 \\
\mathrm{P}<0.05\end{array}$ \\
\hline
\end{tabular}

* Significant at 0.05 level.

From the table 1 it is found the ' $\mathrm{t}$ ' values are significant for neuroticism as well as self-esteem. Hence, the hypothesis is partly accepted. It is important to note down from the table that neuroticism tendency has positive influence on the academic procrastination. Neuroticism is characterized by a low level of emotional stability and impulse control which leads to frustration, anxiety, worry and so on. Higher level of neuroticism leads to anxiety in academic setting and in turn poor academic performance and procrastination. Hence, the influence of neuroticism on academic procrastination is quite logical. This finding is in line with the findings of Johnson \& Bloom (1995), Narges et al. (2014) and Irfan et al. (2015) reported that the neuroticism had significant direct influence on academic procrastination, whereas the other four personality factors were not significantly correlated with academic procrastination.

Also, it is observed that, the self-esteem had significant negative influence on academic procrastination. Self-esteem refers to the ability to evaluate one's own worthiness and it lay a foundation for the development of self confidents and self-regulation. The students with positive self-esteem and the ability to regulate their own behaviour certainly try to complete their academic activities on time rather than postponing it. Hence, the negative influence of selfesteem on academic procrastination is understandable. This finding is in line with the findings of Saleem \& Rafique (2012) as well as Browne (2016) reported negative relationship between procrastination and self-esteem. 
Influence of Personality and Self-Esteem on the Academic Procrastination among University Students

Table: 2 Academic Procrastination of University Students on the basis of Demographic Variables

\begin{tabular}{|c|c|c|c|c|c|}
\hline $\begin{array}{c}\text { Demographic } \\
\text { variable }\end{array}$ & Categories & Mean & S.D & N & 't' value \\
\hline \multirow{2}{*}{ Gender } & Male & 29.97 & 5.36 & 55 & \multirow{2}{*}{$3.61^{*}$} \\
\cline { 2 - 5 } & Female & 26.72 & 4.86 & 82 & \\
\hline Course of study & Arts & 29.75 & 4.96 & 59 & \multirow{2}{*}{$3.36^{*}$} \\
\cline { 2 - 5 } & Science & 26.93 & 4.75 & 78 & \\
\hline \multirow{2}{*}{ Type of family } & Nuclear & 29.54 & 4.77 & 94 & \multirow{2}{*}{$2.56^{*}$} \\
\cline { 2 - 5 } & Joint & 27.15 & 5.20 & 43 & \\
\hline \multirow{2}{*}{ Locality } & Rural & 27.01 & 4.93 & 72 & \multirow{2}{*}{$3.11^{*}$} \\
\cline { 2 - 5 } & Urban & 29.68 & 5.07 & 65 & \\
\hline
\end{tabular}

*Significant at 0.05 level

Table 2 shows the differences in academic procrastination of university students based on their gender, stream of study, locality and type of family. It is found that the 't' values are significant for all the four demographic variables considered in this study. Hence, hypothesis 2 is accepted. It is noticed that male and female students differ significantly in academic procrastination. Males have displayed higher tendency in academic procrastination. Generally, male students in higher education enjoyed a lot of freedom, roam around and spend most of the time in non productive ways. This would exert a lot of pressure on them to complete their curricular activities and hence they may try to procrastinate the academic activities. This finding is inconsistent with the findings of Ozer et al. (2009), Khan et al. (2014) and Browne (2016) reported that male students had higher tendency in academic procrastination. Further, it is observed that the students from arts stream displayed higher academic procrastination than science students. Most of the science subjects have practical work and students have a compulsion to complete their academic activities in a stipulated time. There is no such compulsion in arts subjects and students. Probably this could be the reason that, students from arts discipline had higher tendency in academic procrastination. This findings is supported by the findings of Clariana (2013) indicated that the economic students in universities score higher in academic procrastination.

Students from nuclear families displayed significantly higher score in academic procrastination. In Indian context, the role of family on students' academic performance have been explored by several researchers and indicated that children from joint families performed better than the children of nuclear families (Panda, 1997). In joint families children received proper attention from the elder family members and their activities are monitored. In nuclear families majority of the parents were employed and they find a little time to oversee the activities of their children. This could have enhance the academic procrastination of children from nuclear families. The students from urban area displayed significantly a higher academic procrastination than their counter part. In urban area students have wider opportunities for non academic activities and 
easily distracted by the influences of modernization. Probably this could be the reasons that students from urban area tend to procrastinate higher. This finding is in line with the findings of Steel and Ferrari (2012) reported that urban students had higher academic procrastination in Canadian context.

\section{CONCLUSION}

The findings of this study provided a birds eye view about the problems and facets of procrastination among university students. Neuroticism is the most important factor affecting procrastination. Personality development programmes have to be organized for university students to strengthen their components of personality and enhancing their self-esteem. Students have to be sensitized about the nature and impact of procrastination to face the competition in the global context. Periodical family counselling has to be organized for students with their parents, and parents can be sensitized about this issue. University counselling centers should focus on this issue to ensure personal well being among students.

\section{Acknowledgments}

The author appreciates all those who participated in the study and helped to facilitate the research process.

\section{Conflict of Interests}

The author declared no conflict of interests.

\section{REFERENCES}

Arshad, M., Zaidi, S. M. I. H., \& Mahmood, K. (2015). Self-esteem \& academic performance among university students. Journal of Education and Practice, 6(1), 156-162.

Browne, J. (2016). Self-esteem and procrastination in university students in Barbada. Caribbean Journal of Psychology, 8 (1), 14-24.

Clariana, M. (2013). Personality, procrastination and cheating in students from different university degree programmes. Electronic Journal of Educational Psychology, 11(2), 451-472

Crocker, J., \& Wolfe, C. T. (2001). Contingencies of self-worth. Psychological Review, 108, 593- 623.

Funder D. 1997. The Personality Puzzle. New York: Norton, 1-2.

Hussain, I., \& Sultan, S. (2010). Analysis of procrastination among university students. Procedia Social and Behavioral Sciences,5(1),1897-1904. doi:10.1016 /j.sbspro. 2010.07.385.

Irfan, S., Khizar, U., Murtaza, S., and Iftakhar, I. (2015). Relationship among personality traits, procrastination and coping strategies. International Journal of Advanced Research, 3, (11), 184-193.

Johnson, J.L. \& Bloom, A.M. (1995). An analysis of the contribution of the five factors of personality to variance in academic procrastination. Personality and Individual Differences, 18(1), 127-133. 
Karatas, H. (2015). Correlation among academic procrastination, personality traits, and academic achievement. Anthropologist, 20(1,2), 243-255.

Khan, M.J., Arif, H., Noor, S.S., \& Muneer, S. (2014). Academic procrastination among male and female university and college students. FWU Journal of Social Sciences, 8(2), 65-70.

Lay, C. H. (1986). At last, my research article on procrastination. Journal of Research in Personality, 20, 474-495.

Narges, R., Salman, Z., Baharak, H. (2014). Self-efficacy, perfectionism and personality traits as Predictors of academic procrastination among university students. Journal of Applied Environmental and Biological Sciences, 4(8), 265-271.

Ozer, B.U., Demir, A., \& Ferrari, J.R.(2009). Exploring academic procrastination among Turkish students: Possible gender differences in prevalence and reasons. The Journal of Social Psychology, 149(2), 241-257.

Panda, B.N. (1997). Impact of values, Adjustment and creativity on academic achievement of secondary level students. The Educational Review, C111(11), 1-6.

Roberts, B. W., \& DelVecchio, W. F. (2000). The rank-order consistency of personality traits from childhood to old age: a quantitative review of longitudinal studies. Psychological Bulletin, 126(1), 3-25.

Saleem, M.,\& Rafique, R. (2012). Procrastination and self-esteem among university students. Pakistan Journal of Social and Clinical Psychology, 10(2), 50-53.

Solomon, L. J., \& Rothblum, E. D. (1984). Academic procrastination: frequency and cognitivebehavioral correlates. Journal of Counseling Psychology, 31(4), 503.

Steel, P., and Ferrari, J. (2012). Sex, education and procrastination: An epidemiological study of procrastinators' characteristics from a global sample. European Journal of Personality, doi: 10.1002/per.1851.

Sushma., Kumar, P and Batra, P. (2015). A Study of personality and self-esteem among youth of Rohtak: Haryana. Delhi Psychiatry Journal, 18 (1), 133-137.

How to cite this article: Vijay M, Kadhiravan S (2016), Influence of Personality and SelfEsteem on the Academic Procrastination among University Students, International Journal of Indian Psychology, Volume 4, Issue 1, No. 80, ISSN:2348-5396 (e), ISSN:2349-3429 (p), DIP:18.01.102/20160401, ISBN:978-1-365-57867-0 